(c) American Dairy Science Association, 2007.

\title{
Chloride, Gluconate, Sulfate, and Short-Chain Fatty Acids Affect Calcium Flux Rates Across the Sheep Forestomach Epithelium
}

\author{
S. Leonhard-Marek, ${ }^{1}$ G. Becker, G. Breves, and B. Schröder \\ Department of Physiology, School of Veterinary Medicine, Hannover, Germany
}

\section{ABSTRACT}

In ruminants, more than $50 \%$ of overall gastrointestinal $\mathrm{Ca}$ absorption can occur preintestinally, and the anions of orally applied Ca salts are thought to play an important role in stimulating ruminal $\mathrm{Ca}$ absorption. This assumption is based mainly on ion-exchange studies that have used gluconate as the control anion, which may bind $\mathrm{Ca}^{2+}$ ions and interfere with treatment effects. In the present study, we investigated the distinct effects of different anions on $\mathrm{Ca}$ absorption across the sheep rumen and on the concentration of free $\mathrm{Ca}^{2+}$ ions $\left(\left[\mathrm{Ca}^{2+}\right]_{\text {ion }}\right)$. We showed that gluconate, sulfate, and short-chain fatty acids (SCFA) remarkably reduced $\left[\mathrm{Ca}^{2+}\right]_{\text {ion }}$ in buffer solutions. Nevertheless, increasing the $\mathrm{Cl}$ or SCFA concentration by $60 \mathrm{~m} M$ stimulated net ruminal $\mathrm{Ca}$ absorption 5- to 7-fold, but these effects could be antagonized by gluconate. Therefore, ion-exchange experiments must be (re)evaluated very carefully, because changes in $\left[\mathrm{Ca}^{2+}\right]_{\text {ion }}$ in the presence of gluconate, sulfate, or SCFA not only might entail an underestimation of $\mathrm{Ca}$ flux rates, but also might have effects on other cellular pathways that are $\mathrm{Ca}^{2+}$ dependent. Concerning the optimal Ca supply for dairy cows, the present study suggests that $\mathrm{CaCl}_{2}$ formulations and $\mathrm{Ca}$ salts of the SCFA stimulate Ca absorption across the rumen wall and are beneficial in preventing or correcting a Ca deficiency.

Key words: calcium absorption, chloride, rumen, short-chain fatty acid

\section{INTRODUCTION}

In ruminants, gastrointestinal $\mathrm{Ca}$ absorption can occur in the small (and large) intestine, as is known from $\mathrm{Ca}$ absorption in monogastric animals. In addition, a remarkable proportion of $\mathrm{Ca}$ is absorbed across the epithelium of the rumen (Grace et al., 1974; Rayssiguier and Poncet, 1980), which is the biggest forestomach. In vivo studies with the isolated rumen of sheep have

Received June 9, 2006.

Accepted October 2, 2006.

${ }^{1}$ Corresponding author: sabine.leonhard-marek@tiho-hannover.de shown a net absorption of $5 \mu \mathrm{mol}$ of $\mathrm{Ca}$ per $\mathrm{L}$ and $\mathrm{min}$ (Wadhwa and Care, 2000), which can be extrapolated to a ruminal $\mathrm{Ca}$ absorption of $1.7 \mathrm{~g} / \mathrm{d}$, assuming a volume of $6 \mathrm{~L}$ of rumen fluid. Using the same method, Wagner (1998) measured a ruminal Ca absorption of between 77 and $157 \mu \mathrm{mol} / \mathrm{h}$ per $\mathrm{kg}^{0.75}$ of BW. Because the BW of sheep in Wagner's (1998) study ranged from 48 to $101 \mathrm{~kg}$, this rate can be extrapolated to a ruminal Ca absorption of between 1.3 and $4.8 \mathrm{~g} / \mathrm{d}$.

Feeding experiments have shown that the preintestinal localization of $\mathrm{Ca}$ absorption gains importance if Ca intake increases (Schröder, 1996; Khorasani et al., 1997). Sheep with a Ca intake of $2.7 \mathrm{~g} / \mathrm{d}$ showed a preintestinal $\mathrm{Ca}$ secretion of $0.8 \mathrm{~g} / \mathrm{d}$ and an intestinal $\mathrm{Ca}$ absorption of $1.6 \mathrm{~g} / \mathrm{d}$ (Wylie et al., 1985), whereas sheep with a Ca intake of between 4.8 and $13.6 \mathrm{~g} / \mathrm{d}$ showed a preintestinal Ca absorption of between 0.7 and $4.3 \mathrm{~g} / \mathrm{d}$ and a $\mathrm{Ca}$ secretion in the small intestine of between 1.2 and $2.4 \mathrm{~g} / \mathrm{d}$, which was partly compensated for by Ca absorption in the large intestine (Grace et al., 1974). Comparable observations have been made in cows. Lactating cows with a Ca intake of between 115 and 231 $\mathrm{g} / \mathrm{d}$ showed a preintestinal Ca movement ranging from a small secretion of $-0.9 \mathrm{~g} / \mathrm{d}$ at a low Ca intake to an absorption of $49.8 \mathrm{~g} / \mathrm{d}$ at a high $\mathrm{Ca}$ intake (Khorasani et al., 1997).

The addition of $\mathrm{Ca}$ salts to the diets of cows is a frequent strategy at the onset of lactation, because dairy cows lose considerable amounts of calcium to milk production. Compared with an immediately available $\mathrm{Ca}$ pool of 3 to $4 \mathrm{~g}$ in the circulating blood of a cow (calculated on the basis of $\sim 2.25 \mathrm{mM}$ Ca and $\sim 65 \mathrm{~mL}$ of blood/kg of BW), the Ca drain with milk can amount to $50 \mathrm{~g} / \mathrm{d}$ (assuming a content of $1.2 \mathrm{~g}$ of $\mathrm{Ca} / \mathrm{L}$ of milk). To prevent or correct a $\mathrm{Ca}$ imbalance in lactating cows, $\mathrm{Ca}$ salts are added to their diet (e.g., Ca-chloride, Capropionate). After ingesting the diet, these salts dissociate in the rumen fluid; therefore, the respective anions may influence Ca transport rates across the rumen epithelium.

The mechanisms of ruminal Ca absorption have been studied in small ruminants, where different groups have shown the absorption of $\mathrm{Ca}$ across the rumen of sheep to be stimulated by short-chain fatty acids 
(SCFA; Schröder et al., 1997, 1999; Wadhwa and Care, 2000; Uppal et al., 2003) and by feeding concentrate (Uppal et al., 2003). Further, preliminary studies have suggested a stimulatory effect on ruminal Ca absorption by chloride anions (Leonhard-Marek et al., 2000). However, all those experiments were conducted as anion-exchange in vitro studies in which the anions investigated were replaced by gluconate in the control solutions. This may be a disadvantage, because gluconate is capable of binding $\mathrm{Ca}^{2+}$ ions to some extent (Skibsted and Kilde, 1972; Christoffersen and Skibsted, 1975; Kenyon and Gibbons, 1977). This knowledge has not been considered in most measurements of the $\mathrm{Ca}$ flux rates.

We therefore studied the distinct effects of chloride, SCFA, gluconate, and sulfate on Ca absorption across isolated epithelia from sheep rumen and measured the effects of these anions on ionized $\mathrm{Ca}^{2+}$ concentrations $\left(\left[\mathbf{C a}^{2+}\right]_{\text {ion }}\right)$ in the bathing solutions.

\section{MATERIALS AND METHODS}

\section{Tissues}

The protocol for the animal treatment was approved and its conduct supervised by the animal protection officer of the Department of Physiology, School of Veterinary Medicine. Adult male and female German blackheaded mutton sheep (19 animals, 7 to 8 mo of age) were killed by captive bolt stunning followed by exsanguination from the carotid arteries. Within $5 \mathrm{~min}$ after slaughter, a piece of about $15 \times 20 \mathrm{~cm}$ of the ventral rumen wall was taken and immediately immersed in a buffer solution containing SCFA (solution A; Table 1) at $38^{\circ} \mathrm{C}$, where the mucosa was stripped from the underlying muscle layers and the serosa (LeonhardMarek et al., 1998). The tissue was then cut into smaller pieces of about $2 \times 2 \mathrm{~cm}$.

\section{Solutions}

Because SCFA are the major anions on the luminal side under in vivo conditions, we started the first experiments with a physiological SCFA gradient across the rumen wall. Epithelia were bathed with buffer solutions containing a mixture of $60 \mathrm{~m} M$ SCFA on the mucosal side (Table 1, buffer A). These SCFA anions were replaced by $60 \mathrm{~m} M$ gluconate in the solution bathing the serosal side of the epithelia (buffer C). Both solutions contained $68 \mathrm{mMCl}$. In these first experiments, $\mathrm{Cl}$ was replaced by gluconate to obtain a low-Cl solution (buffer B).

In the second series of experiments, we (re)evaluated the effects of different anions on Ca flux rates, starting from a control buffer that contained mannitol (and no gluconate, buffer D; Table 1). To obtain different anion solutions, we replaced mannitol by Tris-OH and the respective acid (hydrochloric acid, sulfuric acid, or SCFA, buffers E to G; Table 1).

The compositions of the different solutions are presented in Table 1 . All solutions had a $\mathrm{pH}$ of 7.4 when gassed with $95 \% \mathrm{O}_{2}$ and $5 \% \mathrm{CO}_{2}$ at $38^{\circ} \mathrm{C}$ and an osmolarity of $300 \mathrm{mosmol} / \mathrm{L}$. All chemicals were of analytical grade and were obtained from Merck (Darmstadt, Germany) or from Sigma-Aldrich (Deisenhofen, Germany).

\section{Electrical Measurements}

Mucosal tissues were mounted between the two halves of Ussing incubation chambers (Department of Physiology, School of Veterinary Medicine, Hannover, Germany) with an exposed area of $1.13 \mathrm{~cm}^{2}$. Damage to the tissue edges was minimized by placing rings of silicon rubber on both sides of the tissues. Incubation chambers were connected to circulation reservoirs (glassblower shop, Hannover Medical School, Hannover, Germany) containing $10 \mathrm{~mL}$ of buffer solution on each side. The solutions were maintained at $38^{\circ} \mathrm{C}$ by a water jacket and were continuously stirred by use of a gas lift system that supplied $95 \% \mathrm{O}_{2}$ and $5 \% \mathrm{CO}_{2}$. The Ussing chambers were also connected to a computercontrolled voltage clamp device (Mussler Scientific Instruments, Aachen, Germany). Transepithelial potential differences $\left(\mathbf{V}_{\mathbf{t}}\right)$ were measured through buffer solution agar bridges and calomel electrodes with reference to the mucosal solution. Transepithelial tissue conductances $\left(\mathbf{G}_{\mathbf{t}}\right)$ were determined from the changes in $V_{t}$ induced by bipolar current pulses of $100 \mu \mathrm{A} / \mathrm{cm}^{2}$ of 500 ms duration. The currents were passed through buffer solution agar bridges connected to $\mathrm{Ag}-\mathrm{AgCl}$ electrodes in $3 \mathrm{M} \mathrm{KCl}$. In each setup, fluid resistances and junction potentials were measured before mounting the mucosal tissues and were corrected for during the experiments. The experiments were performed under short-circuit conditions, unless otherwise stated.

\section{Ca Flux Rates}

Unidirectional flux rates of $\mathrm{Ca}$ were measured using ${ }^{45} \mathrm{Ca}$ as a tracer, which was added as ${ }^{45} \mathrm{CaCl}_{2}$ (specific activity $>370 \mathrm{GBq} / \mathrm{g}$; PerkinElmer Life Sciences, Rodgau-Jügesheim, Germany) in each chamber to the mucosal or the serosal side of the epithelia. After an equilibration period of $20 \mathrm{~min}, 10$ to 12 buffer samples of 500 $\mu \mathrm{L}$ were taken at 30 -min intervals and replaced by aliquots of the same unlabeled solution. Radioactivity was measured in a conventional liquid scintillation counter (Tricarb Packard, Dreieich, Germany). Flux rates were calculated from the rate of tracer appearance 
Table 1. Composition of the buffer solutions ${ }^{1}$

\begin{tabular}{|c|c|c|c|c|}
\hline \multirow[b]{2}{*}{ Composition } & \multicolumn{4}{|c|}{ Experiment 1} \\
\hline & $\begin{array}{c}\text { Buffer A, } \\
\text { high Cl/SCFA }\end{array}$ & \multicolumn{2}{|c|}{$\begin{array}{l}\text { Buffer B, low Cl/ } \\
\text { SCFA gluconate }\end{array}$} & $\begin{array}{l}\text { Buffer C, high Cl/ } \\
\text { SCFA-free gluconate }\end{array}$ \\
\hline $\mathrm{NaCl}$ & 57 & \multicolumn{2}{|c|}{ - } & 57 \\
\hline $\mathrm{KCl}$ & 5 & \multirow{2}{*}{\multicolumn{2}{|c|}{5}} & 5 \\
\hline $\mathrm{HCl}$ & 0.8 & & & 0.4 \\
\hline $\mathrm{CaCl}_{2}$ & 1.2 & \multicolumn{2}{|c|}{1.2} & 1.2 \\
\hline $\mathrm{MgCl}_{2}$ & 1.2 & \multicolumn{2}{|c|}{1.2} & 1.2 \\
\hline $\mathrm{NaHCO}_{3}$ & 21 & \multirow{2}{*}{\multicolumn{2}{|c|}{$\begin{array}{l}21 \\
1.2\end{array}$}} & 21 \\
\hline $\mathrm{Na}_{2} \mathrm{HPO}_{4}$ & 1.2 & & & 1.4 \\
\hline $\mathrm{NaH}_{2} \mathrm{PO}_{4}$ & 1.6 & \multicolumn{2}{|c|}{1.6} & 1.4 \\
\hline Glucose & - & \multicolumn{2}{|c|}{ - } & 5 \\
\hline Na-acetate & 36 & \multirow{2}{*}{\multicolumn{2}{|c|}{$\begin{array}{l}36 \\
15\end{array}$}} & - \\
\hline Na-propionate & 15 & 15 & & - \\
\hline Na- $n$-butyrate & 9 & \multicolumn{2}{|c|}{9} & - \\
\hline Na-gluconate & 1.2 & \multicolumn{2}{|c|}{$\begin{array}{l}58.2 \\
23\end{array}$} & 61 \\
\hline \multirow[t]{2}{*}{ Mannitol } & 18 & 23 & & 20 \\
\hline & \multicolumn{4}{|c|}{ Experiment 2} \\
\hline Composition & $\begin{array}{c}\text { Buffer D, } \\
\text { control/mannitol }^{2,3}\end{array}$ & $\begin{array}{l}\text { Buffer E, } \\
{\text { high } \mathrm{Cl}^{2}}^{2}\end{array}$ & $\begin{array}{l}\text { Buffer F, } \\
\text { high } \mathrm{SO}_{4}{ }^{2}\end{array}$ & $\begin{array}{c}\text { Buffer G, } \\
\text { high SCFA }\end{array}$ \\
\hline $\mathrm{KCl}$ & 5 & 5 & 5 & 5 \\
\hline $\mathrm{CaCl}_{2}$ & 1.2 & 1.2 & 1.2 & 1.2 \\
\hline $\mathrm{MgCl}_{2}$ & 1.2 & 1.2 & 1.2 & 1.2 \\
\hline $\mathrm{NaHCO}_{3}$ & 21 & 21 & 21 & 21 \\
\hline $\mathrm{Na}_{2} \mathrm{HPO}_{4}$ & 1.2 & 1.2 & 1.2 & 1.2 \\
\hline $\mathrm{NaH}_{2} \mathrm{PO}_{4}$ & 1.6 & 1.6 & 1.6 & 1.6 \\
\hline Glucose & 10 & 10 & 10 & 10 \\
\hline $\mathrm{HCl}$ & 1 & 60.2 & 0.2 & 0.2 \\
\hline $\mathrm{H}_{2} \mathrm{SO}_{4}$ & - & - & 30 & - \\
\hline Acetic acid & - & - & - & 36 \\
\hline Propionic acid & - & - & - & 15 \\
\hline$n$-Butyric acid & - & - & - & 9 \\
\hline Tris-OH & - & 65.9 & 116 & 70 \\
\hline Mannitol & 217.5 & 110 & 90 & 100 \\
\hline
\end{tabular}

${ }^{1}$ Concentrations are given in $\mathrm{m} M$. SCFA = short-chain fatty acids.

${ }^{2}$ Solution used on the mucosal side of the epithelia.

${ }^{3}$ Solution used on the serosal side of the epithelia.

on the other side of the epithelia. In the absence of any manipulation, flux rates were stable from the second to the ninth flux period in the epithelia used for the experiments under short-circuit conditions, and from the third to the eleventh flux period in the epithelia used for the voltage clamp experiments. On the basis of steady-state values, a mean flux rate was calculated for each epithelial sheet and each condition. The effects of different anions on $\mathrm{Ca}$ flux rates were tested with adjacent pieces of epithelia from the same sheep.

To study the effect of different transepithelial potential differences on Ca flux rates, we incubated 2 epithelia for each buffer solution and each flux direction from each sheep. One of these tissues was subsequently clamped to $-25,+25$, and $0 \mathrm{mV}$, and the other tissue was clamped to $+25,-25$, and $0 \mathrm{mV}$. To exclude an influence of the sequence of the applied potential differences, the steady-state fluxes measured at the respective $V_{t}$ were averaged between the 2 tissues. Unidirec- tional fluxes measured at different potential differences were divided into their electrogenic and electroneutral components according to a mathematical model described by Frizzell and Schultz (1972): $\mathbf{J}=\mathbf{J}_{\mathbf{d}} \cdot \xi^{-0.5}+$ $\mathbf{J}_{\mathbf{m}}$, and $\xi=\mathrm{e}^{(\mathbf{z F V} / \mathbf{R T})}$, where $\mathbf{J}$ is the total unidirectional flux of an ion, $\mathbf{J}_{\mathbf{d}} \cdot \xi^{0.5}$ is its diffusible (electrogenic) part, and $\mathbf{J}_{\mathbf{m}}$ is its electroneutral (voltage-independent) proportion. $\mathbf{V}$ gives the potential difference across the epithelium in flux direction, $\mathbf{z}$ is the valence of the ion, $\mathbf{F}$ is the Faraday constant, $\mathbf{R}$ is the gas constant, and $\mathbf{T}$ is the absolute temperature.

Calcium flux rates were measured 1) in the presence of gluconate or chloride (corresponding to the classical ion-exchange experiments) and at different transepithelial potential differences (allowing for the calculation of electrogenic and electroneutral flux components); 2) in the presence of gluconate and chloride (to follow up on the distinct effects of each anion on the same tissues; see below); and 3) in the absence of gluco- 


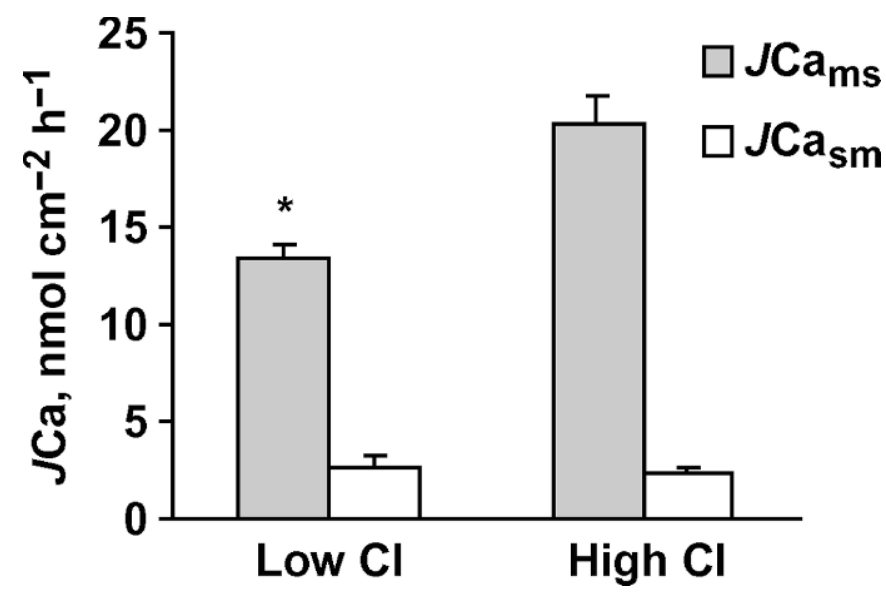

Figure 1. Calcium flux rates at different $\mathrm{Cl}$ concentrations on the mucosal side. $J \mathrm{Ca}_{\mathrm{ms}}=\mathrm{Ca}$ flux rate from the mucosal to the serosal side $(\mathrm{n}=12) ; \mathrm{JCa}_{\mathrm{sm}}=\mathrm{Ca}$ flux rate from the serosal to the mucosal side $(\mathrm{n}=6)$. Low $\mathrm{Cl}(10 \mathrm{~m} M \mathrm{Cl}, 58 \mathrm{~m} M$ gluconate; buffer $\mathrm{B})$, high $\mathrm{Cl}$ $\left(68 \mathrm{~m} M \mathrm{Cl}\right.$; buffer A); ${ }^{*} P<0.05$ vs. high $\mathrm{Cl}$.

nate (allowing us to monitor the specific effect of an anion in relation to a mannitol control).

For the second purpose, we added gluconate to a high$\mathrm{Cl}$ solution or $\mathrm{Cl}$ to a high-gluconate solution. The addition of these salts increased the osmolarity by about $100 \mathrm{mosmol} / \mathrm{L}$ on the luminal side. This increase is in the range of changes that can occur after food intake (Warner and Stacy, 1965; von Engelhardt, 1969) and induces changes in transepithelial conductance that can be measured in in vitro studies. These increases in $G_{t}$ have been attributed to an increase in passive paracellular movements (Schweigel et al., 2005). Apart from these osmolarity-induced increases in $G_{t}$, the transepithelial conductance, which was taken as a measure of tissue viability, remained stable for the duration of the experiments.

\section{Ionized $\mathrm{Ca}^{2+}$}

The concentrations of free $\mathrm{Ca}^{2+}$ ions in the solutions were measured with a blood gas and electrolyte analyzer (Bayer Diagnostics, Fenwald, Germany) equipped with an ion-selective $\mathrm{Ca}^{2+}$ electrode. Samples were analyzed at $37^{\circ} \mathrm{C}$ and corrected to a $\mathrm{pH}$ of 7.4 . The ionized $\mathrm{Ca}^{2+}$ concentration was measured 1) in gluconate and $\mathrm{Cl}$ solutions at different times, in parallel to the protocol that had been used for the flux experiments; 2) after addition of gluconate or chloride; and 3) in mannitol, sulfate, and SCFA solutions.

\section{Statistics}

Results are given as means \pm standard error of the means. Unless otherwise stated, $\mathrm{n}$ represents the num- ber of tissues. Wherever possible, 2 pieces of tissues were incubated per animal and per experimental condition. Epithelial preparations that showed large unspecific increases in transepithelial conductance were excluded from the experiments. Most experiments were conducted with tissues from a group of 6 animals; in 2 instances, 9 and 4 animals were available. Statistical significance was evaluated using ANOVA (one-way) if 3 or more groups had to be compared. For the comparison of 2 conditions, we used Student's $t$-test, paired or unpaired as appropriate. A value of $P<0.05$ was considered significant.

\section{RESULTS}

\section{Ca Flux Rates in the Presence of Gluconate or Chloride}

In the first experiments with a physiological SCFA gradient across the rumen wall, epithelia were bathed with buffer solutions containing a mixture of $60 \mathrm{mM}$ SCFA on the mucosal side (buffer A; Table 1). These SCFA anions were replaced by gluconate on the serosal side of the epithelia (buffer C). Both solutions contained $68 \mathrm{~m} M \mathrm{Cl}$. Under this high-Cl condition, we observed a Ca flux rate from the mucosal to the serosal side $\left(\boldsymbol{J C a}_{\mathbf{m s}}\right)$ of $20.3 \pm 1.4 \mathrm{nmol} \mathrm{cm}^{-2} \mathrm{~h}^{-1}(\mathrm{n}=12$; Figure 1$)$ and a Ca flux rate from the serosal to the mucosal compartment $\left(\boldsymbol{J C a}_{\mathrm{sm}}\right)$ of $2.3 \pm 0.4 \mathrm{nmol} \mathrm{cm} \mathrm{ch}^{-2} \mathrm{~h}^{-1}(\mathrm{n}=$ 6), resulting in a significant net $\mathrm{Ca}$ absorption $\left(\boldsymbol{J C} \mathbf{C a}_{\text {net }}=\right.$ $\left.J \mathrm{Ca}_{\mathrm{ms}}-J \mathrm{Ca}_{\mathrm{sm}}\right)$ of $18.0 \pm 1.1 \mathrm{nmol} \mathrm{cm} \mathrm{cm}^{-1}(\mathrm{n}=6)$ across the rumen epithelium.

Adjacent epithelia from the same animals were incubated with a reduced $\mathrm{Cl}$ concentration on the mucosal side (10 $\mathrm{m} M \mathrm{Cl}$ and $58 \mathrm{~m} M$ gluconate; buffer B). This altered luminal condition had no effect on $\mathrm{JCa}_{\mathrm{sm}}(2.7$ $\pm 0.5 \mathrm{nmol} \mathrm{cm}^{-2} \mathrm{~h}^{-1}, \mathrm{n}=6$; Figure 1 ), but $J \mathrm{Ca}_{\mathrm{ms}}$ was significantly reduced to $13.4 \pm 0.7 \mathrm{nmol} \mathrm{cm}{ }^{-2} \mathrm{~h}^{-1}$ ( $\mathrm{n}=$ $12, P<0.001$ vs. high $\mathrm{Cl}$ ). The $J \mathrm{Ca}_{\text {net }}$ was reduced to $10.7 \pm 1.1 \mathrm{nmol} \mathrm{cm}^{-2} \mathrm{~h}^{-1}(\mathrm{n}=6)$.

The results (Figure 1) showed a significant effect of $\mathrm{Cl}$ (or gluconate) on $\mathrm{JCa}_{\mathrm{ms}}$ under short-circuit conditions (at zero electrochemical potential). Subsequently, we measured $J \mathrm{Ca}_{\mathrm{ms}}$ and $J \mathrm{Ca}_{\mathrm{sm}}$ at $+25,0$, and $-25 \mathrm{mV}$ of $\mathrm{V}_{\mathrm{t}}$. The analysis of these Ca flux rates at varying $\mathrm{V}_{\mathrm{t}}$ (according to Frizzell and Schultz, 1972; see the Materials and Methods section) and linear regressions of the Ca fluxes on the electric driving force $\left(\xi^{\mathbf{0 . 5}}\right)$ resulted in the following equations ( $n=27$ observations in 9 sheep):

High-Cl

$$
\begin{aligned}
& J C a_{\mathrm{ms}}=10.4( \pm 2.5)+9.6( \pm 1.6) \xi^{0.5} \\
& \left(\mathrm{r}^{2}=0.604, P<0.001\right)
\end{aligned}
$$




$$
\begin{aligned}
& J \mathrm{Ca}_{\mathrm{sm}}=2.1( \pm 0.6)+1.1( \pm 0.4) \xi^{-0.5} \\
& \left(\mathrm{r}^{2}=0.255, P<0.01\right)
\end{aligned}
$$

Low-Cl

$$
\begin{aligned}
& J \mathrm{Ca}_{\mathrm{ms}}=6.8( \pm 1.8)+6.4( \pm 1.1) \xi^{-0.5} \\
& \left(\mathrm{r}^{2}=0.576, P<0.001\right) \\
& J \mathrm{Ca}_{\mathrm{sm}}=3.5( \pm 0.6)+1.1( \pm 0.4) \xi^{-0.5} \\
& \left(\mathrm{r}^{2}=0.225, P<0.05\right) .
\end{aligned}
$$

A comparison of the $\mathrm{Cl}$ effects on the basis of the number of animals $(n=9)$ showed that $\mathrm{Cl}$ increased both the electrogenic and the electroneutral component of $J \mathrm{Ca}_{\mathrm{ms}}(P<0.01)$. Chloride also had a small but significant effect on the electroneutral component of $J \mathrm{Ca}_{\mathrm{sm}}$ $(P<0.05)$, whereas the electrogenic component of $J \mathrm{Ca}_{\mathrm{sm}}$ remained unaffected.

\section{Ca Flux Rates in the Presence of Gluconate and Chloride}

This first study, corresponding to the classical ionexchange experiments, did not allow us to discriminate between a stimulatory effect of $\mathrm{Cl}$ or a blocking effect of gluconate. We therefore simulated an additional salt intake after the fifth flux period and added $58 \mathrm{mM} \mathrm{NaCl}$ to the luminal side of the epithelia bathed in the low-Cl (and high-gluconate) buffer. At the same time, adjacent epithelia that were incubated in a high-Cl (and lowgluconate) buffer received an addition of $58 \mathrm{mM} \mathrm{Na}-$ gluconate to the luminal side (Figure 2). Both groups of epithelia thus faced the same composition of buffer solution during the final flux rates.

Addition of these salts increased osmolarity by about $100 \mathrm{mosmol} / \mathrm{L}$ on the luminal side and induced an increase in $\mathrm{G}_{\mathrm{t}}$ from $2.0 \pm 0.2$ to $3.1 \pm 0.3 \mathrm{mS} \mathrm{cm}^{-2}(\mathrm{n}=6$, $P<0.001)$ after the addition of $\mathrm{NaCl}$, and from $2.2 \pm$ 0.2 to $3.2 \pm 0.2 \mathrm{mS} \mathrm{cm}^{-2}(\mathrm{n}=6, P<0.001)$ after the addition of Na-gluconate. This increase in $\mathrm{G}_{\mathrm{t}}$ was accompanied by a parallel increase in $J \mathrm{Ca}_{\mathrm{sm}}$, from $2.7 \pm$ 0.5 to $6.1 \pm 1.2 \mathrm{nmol} \mathrm{cm}^{-2} \mathrm{~h}^{-1}$ after the addition of $\mathrm{NaCl}$ and from $2.3 \pm 0.4$ to $6.6 \pm 1.2 \mathrm{nmol} \mathrm{cm}{ }^{-2} \mathrm{~h}^{-1}$ after Nagluconate (for both groups $\mathrm{n}=6, P<0.01$ ), in line with an increased paracellular conductance.

Despite the changes in the paracellular pathway, the addition of $\mathrm{Cl}$ ions to the low-Cl, high-gluconate solution had no effect on $J \mathrm{Ca}_{\mathrm{ms}}\left(14.0 \pm 1.1 \mathrm{nmol} \mathrm{cm}^{-2} \mathrm{~h}^{-1}\right.$ before vs. $13.1 \pm 2.4 \mathrm{nmol} \mathrm{cm}^{-2} \mathrm{~h}^{-1}$ after addition of chloride, $\mathrm{n}=6$ ). In contrast, the addition of gluconate to the high$\mathrm{Cl}$, low-gluconate solution reduced $\mathrm{JCa}_{\mathrm{ms}}$ from $18.9 \pm$ $1.8 \mathrm{nmol} \mathrm{cm}{ }^{-2} \mathrm{~h}^{-1}$ (before addition of gluconate) to 11.5

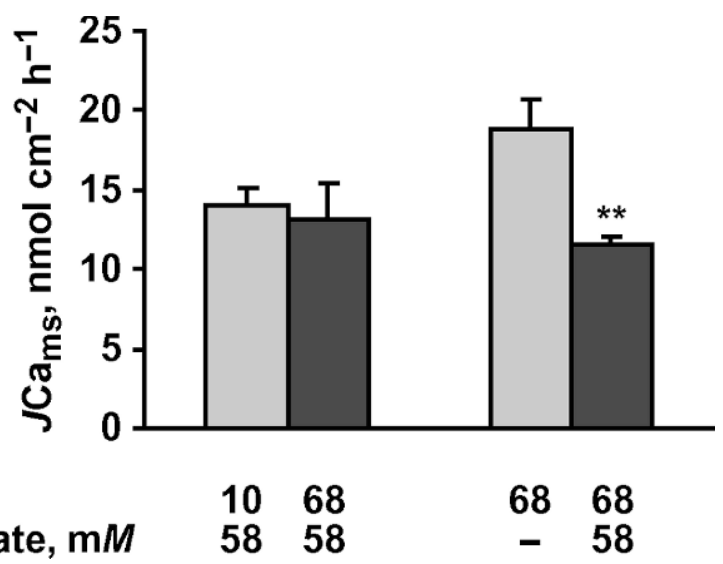

Figure 2. Calcium flux rates from the mucosal to the serosal side $\left(J \mathrm{Ca}_{\mathrm{ms}}\right)$ at different $\mathrm{Cl}$ and gluconate concentrations on the mucosal side. For the first column of each pair (gray bars), we calculated a mean flux rate for each epithelium on the basis of steady-state $\mathrm{Ca}$ fluxes from the second to the fifth flux period. The second column of each pair (black bars) represents the eighth flux period (between 50 and 80 min after addition of $\mathrm{Cl}$ or gluconate, $\mathrm{n}=6$ ); $* * P<0.01$ vs. $68 \mathrm{~m} M \mathrm{Cl}$, gluconate free.

$\pm 0.5 \mathrm{nmol} \mathrm{cm}^{-2} \mathrm{~h}^{-1}(\mathrm{n}=6, P<0.01$; Figure 2). These data showed that, in a standard ion-exchange experiment, the higher $\mathrm{Ca}$ flux rates in a $\mathrm{Cl}$ buffer were not due to a stimulating effect of $\mathrm{Cl}$, but could be attributed to a blocking effect of gluconate in the control solution.

\section{Ionized $\mathrm{Ca}^{2+}$ Concentration in Gluconate and $\mathrm{Cl}$ Solutions}

The extent of $J \mathrm{Ca}_{\mathrm{ms}}$ reduction attributable to gluconate was rather astonishing. We therefore expanded the study by measuring the concentration of free $\mathrm{Ca}^{2+}$ ions in all buffer solutions (Figure 3). All buffer solutions had a total Ca concentration of $1.2 \mathrm{mM}$. Of these we found $0.8 \pm 0.02 \mathrm{mM}\left[\mathrm{Ca}^{2+}\right]_{\text {ion }}$ in the high-Cl (SCFA) solution (buffer $\mathrm{A} ; \mathrm{n}=4$ freshly prepared solutions), but only $0.2 \pm 0.0 \mathrm{mM}\left[\mathrm{Ca}^{2+}\right]_{\text {ion }}$ in the low-Cl solution (high-gluconate and SCFA, buffer B; $\mathrm{n}=3$ solutions). The buffer solution on the serosal side (high-Cl, highgluconate, no SCFA, buffer C) showed a $\left[\mathrm{Ca}^{2+}\right]_{\text {ion }}$ concentration of $0.3 \pm 0.03 \mathrm{mM}(\mathrm{n}=4$ solutions $)$. These concentrations of $\left[\mathrm{Ca}^{2+}\right]_{\text {ion }}$ did not change between measurements carried out in the buffer reservoir in the Ussing chambers 5 min before the placement of the epithelia and $300 \mathrm{~min}$ after incubation of the epithelia (Figure 3 ), indicating that the tissues themselves had no effect on the concentration of $\left[\mathrm{Ca}^{2+}\right]_{\text {ion }}$. We then repeated the $\mathrm{Ca}$ flux protocol and added Na-gluconate or $\mathrm{NaCl}(58$ $\mathrm{m} M$ each) to the buffer solutions on the mucosal side. Gluconate immediately decreased the concentration of free $\mathrm{Ca}^{2+}$ ions to $0.3 \pm 0.01 \mathrm{mM}(P<0.001, \mathrm{n}=5$; Figure 3 ), in parallel with the reduction of the $\mathrm{Ca}$ flux rates 


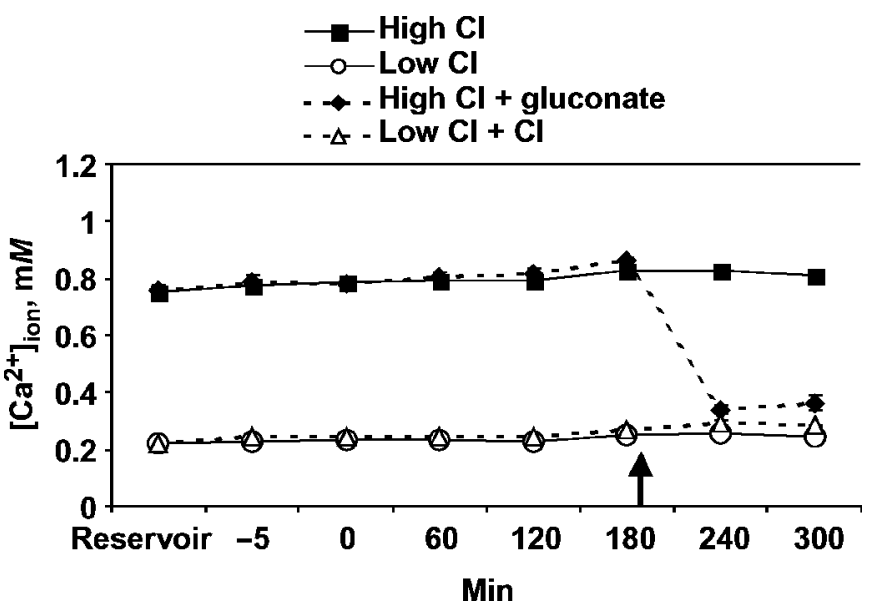

Figure 3. Concentration of free $\mathrm{Ca}$ ions $\left(\left[\mathrm{Ca}^{2+}\right]_{\text {ion }}\right)$ in different buffer solutions during the course of a flux experiment. Buffer solutions are the same as in the flux experiment presented in Figure 2. High $\mathrm{Cl}(68 \mathrm{~m} M \mathrm{Cl}$; buffer A), low $\mathrm{Cl}(10 \mathrm{~m} M$ Cl, $58 \mathrm{~m} M$ gluconate; buffer $\mathrm{B}$ ), + gluconate or $+\mathrm{Cl}$ (addition of $58 \mathrm{~m} M$ Na-gluconate or $58 \mathrm{~m} M \mathrm{NaCl}$, respectively, to the mucosal side at $\mathrm{t}=190 \mathrm{~min}$, shown by the arrow; $n=4$ to 5 ). Means \pm SEM (some error bars are smaller than the symbols).

shown above ( $J \mathrm{Ca}_{\mathrm{ms}} ;$ Figure 2$)$. Chloride, which had no effect on $J \mathrm{Ca}_{\mathrm{ms}}$ (Figure 2), had also almost no effect on the concentration of free $\mathrm{Ca}^{2+}$ ions $(0.27 \pm 0.01 \mathrm{mM}$ before and $0.29 \pm 0.01 \mathrm{mM}$ after addition of $58 \mathrm{mM}$ $\mathrm{NaCl}, P=0.07, \mathrm{n}=5$; Figure 3 ).

The results of our first experiment thus showed us a huge effect of gluconate on $\mathrm{Ca}$ flux rates, which called into question the anion effects of $\mathrm{Cl}$ and SCFA reported in the literature (using gluconate as the control anion).

\section{Effect of Anions on Ca Fluxes (Without Gluconate)}

In a second series, we (re)evaluated the effects of different anions on Ca flux rates, starting from a control buffer that contained mannitol (and no gluconate; buffer $\mathrm{D}$ in Table 1). To obtain different anion solutions, we replaced mannitol by Tris-OH and the respective acid (hydrochloric acid, sulfuric acid, or SCFA; buffers $\mathrm{E}$ to $\mathrm{G}$ in Table 1 and Figure 4).

Under control conditions, $J \mathrm{Ca}_{\mathrm{ms}}$ amounted to $8.3 \pm$ $0.4 \mathrm{nmol} \mathrm{cm} \mathrm{ch}^{-2} \mathrm{~h}^{-1}$ and $J \mathrm{Ca}_{\mathrm{sm}}$ to $6.2 \pm 0.4 \mathrm{nmol} \mathrm{cm}{ }^{-2}$ $\mathrm{h}^{-1}$. Changing the luminal condition to different dominant anions had no effect on $J \mathrm{Ca}_{\mathrm{sm}}$. Luminal sulfate also had no effect on $J \mathrm{Ca}_{\mathrm{ms}}$. However, increasing the luminal concentration of $\mathrm{Cl}$ and SCFA significantly increased $J \mathrm{Ca}_{\mathrm{ms}}$, which resulted in significant net absorption rates for $\mathrm{Ca}$ under these conditions (Figure 4).

\section{lonized $\mathrm{Ca}^{2+}$ Concentration in $\mathrm{Cl}$, SCFA, and Sulfate Solutions}

To compare the observed Ca flux rates to the concentration of free $\mathrm{Ca}^{2+}$ ions, we again measured the concen-

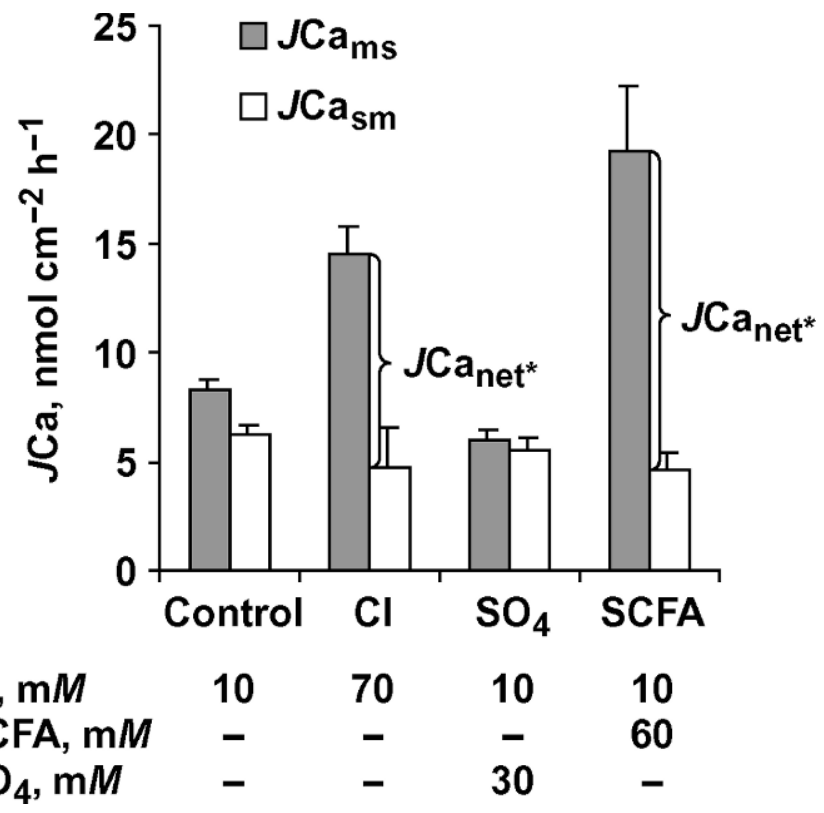

Figure 4. Calcium flux rates measured in the presence of different dominant anions on the mucosal side. $J \mathrm{Ja}_{\mathrm{ms}}=\mathrm{Ca}$ flux rate from the mucosal to the serosal side; $J \mathrm{Ca}_{\mathrm{sm}}=\mathrm{Ca}$ flux from the serosal to the mucosal side; $J \mathrm{Ca}_{\text {net }}=$ net $\mathrm{Ca}$ absorption; $\mathrm{SCFA}=$ short-chain fatty acids. Buffers D to $\mathrm{G}$ are described in Table $1 ; \mathrm{n}=4$ to 8 epithelia from 4 sheep. ${ }^{*} P<0.05$, significant net absorption for $J \mathrm{Ca}_{\mathrm{ms}} \mathrm{vs} . J C a_{\mathrm{sm}}$.

tration of ionized $\mathrm{Ca}^{2+}$ in these solutions. As in the first series, the total Ca concentration amounted to $1.2 \mathrm{mM}$ in all buffer solutions. These measurements showed that not only gluconate, but also sulfate and SCFA could reduce the concentration of ionized $\mathrm{Ca}^{2+}$ (Table 2), which was not always correlated with a reduction in the Ca flux rate.

\section{DISCUSSION}

\section{Effects of $\mathrm{Cl}$ on Ruminal Ca Absorption}

Because $\mathrm{CaCl}_{2}$ is frequently used as an oral therapeutic in cases of suspected or diagnosed hypocalcemia in ruminants, we wanted to know whether $\mathrm{Cl}$ ions might influence $\mathrm{Ca}$ absorption across the rumen wall. $\mathrm{Al}$ though a high $\mathrm{Ca}$ intake has been shown to result in preintestinal $\mathrm{Ca}$ absorption in sheep and cows, the mechanisms involved in ruminal $\mathrm{Ca}$ transport have been studied more intensively in sheep. To allow for a better comparison with data from the literature, we conducted this study with epithelia from sheep rumen. To study the isolated effects of $\mathrm{Cl}$ ions, we exchanged mannitol for Tris-Cl without increasing the free $\mathrm{Ca}^{2+}$ concentration (Table 1) and found that $\mathrm{Cl}$ is indeed able to stimulate $\mathrm{JCa}_{\mathrm{ms}}$ and net $\mathrm{Ca}$ absorption from the rumen (Figure 4). 
Table 2. Effect of different selected anions on the concentration of free $\mathrm{Ca}^{2+}$ ions and $\mathrm{Ca}^{2+}$ flux rates ${ }^{1}$

\begin{tabular}{lcccc}
\hline Anion & $\begin{array}{c}\text { Buffer D, } \\
\text { control }\end{array}$ & $\begin{array}{c}\text { Buffer E, } \\
\text { high Cl }\end{array}$ & $\begin{array}{c}\text { Buffer F, } \\
\text { high SO }\end{array}$ & $\begin{array}{c}\text { Buffer G, } \\
\text { high SCFA }\end{array}$ \\
\hline $\mathrm{Cl}^{-}, \mathrm{m} M$ & 10 & 70 & 10 & 10 \\
$\mathrm{SCFA}^{-}, \mathrm{m} M$ & 0 & 0 & 0 & 60 \\
$\mathrm{SO}_{4}^{2-}, \mathrm{m} M$ & 0 & 0 & 30 & 0 \\
{$\left[\mathrm{Ca}^{2+}\right]_{\text {ion }}, \mathrm{m} M$} & $1.11 \pm 0.01$ & $1.02 \pm 0.00^{*}$ & $0.36 \pm 0.01^{*}$ & $0.77 \pm 0.01^{*}$ \\
$J \mathrm{Ja}_{\mathrm{ms}}, \mathrm{nmol} \mathrm{cm}{ }^{-2} \mathrm{~h}^{-1}$ & $8.3 \pm 0.4$ & $14.5 \pm 1.4$ & $6.0 \pm 0.5$ & $19.2 \pm 3.0$ \\
\hline
\end{tabular}

${ }^{1}$ Other unnamed anions were kept at a constant level (see Table 1 ). $\left[\mathrm{Ca}^{2+}\right]_{\text {ion }}=$ concentration of free $\mathrm{Ca}^{2+}$ ions $(\mathrm{n}=4), * P<0.05$ vs. control; $\mathrm{JCa}_{\mathrm{ms}}=\mathrm{Ca}^{2+}$ flux rate from the mucosal to the serosal side ( $\mathrm{n}=6$ to 8 epithelia from 4 sheep).

Calcium absorption across the sheep rumen epithelium is at least partly active (Höller et al., 1988; Schröder et al., 1997) and involves electrogenic and electroneutral components (Höller et al., 1988; Wadhwa and Care, 2000), which was confirmed here. The electrogenic component of $J \mathrm{Ca}_{\mathrm{ms}}$ cannot be explained by mere paracellular transport, because it clearly differed from the respective component of $\mathrm{JCa}_{\mathrm{sm}}$. The majority of potential-dependent $J \mathrm{Ca}_{\mathrm{ms}}$ has therefore to be considered as an electrogenic transport through the cells (Figure $5)$. Both components of $J \mathrm{Ca}_{\mathrm{ms}}$, electrogenic and electroneutral, were stimulated by mucosal $\mathrm{Cl}$ in the present study.

The current concept of $\mathrm{Cl}$ absorption across the rumen epithelium assumes an electroneutral $\mathrm{Cl}$ uptake across the apical membrane via $\mathrm{Cl}^{-} / \mathrm{HCO}_{3}{ }^{-}$exchange
(Chien and Stevens, 1972; Martens et al., 1991). Candidates for this exchange are anion exchanger 2 , the intestinal anion exchanger DRA (down-regulated in adenoma), and the putative anion transporter 1 , which have been shown on the mRNA level in rumen epithelia and cultured rumen epithelial cells from sheep (Bilk et al., 2005). Recent patch clamp experiments with isolated rumen epithelial cells showed that rumen epithelial cells also express a $\mathrm{Cl}^{-}$conductance (LeonhardMarek et al., 2005). In microelectrode experiments, where we impaled rumen epithelium via the apical membrane, we could show that this $\mathrm{Cl}^{-}$conductance must be localized in the basolateral membranes of rumen epithelial cells (Leonhard-Marek et al., 2006), where it might contribute to the transepithelial transport of $\mathrm{Cl}$, as suggested for basolateral-localized $\mathrm{Cl}$

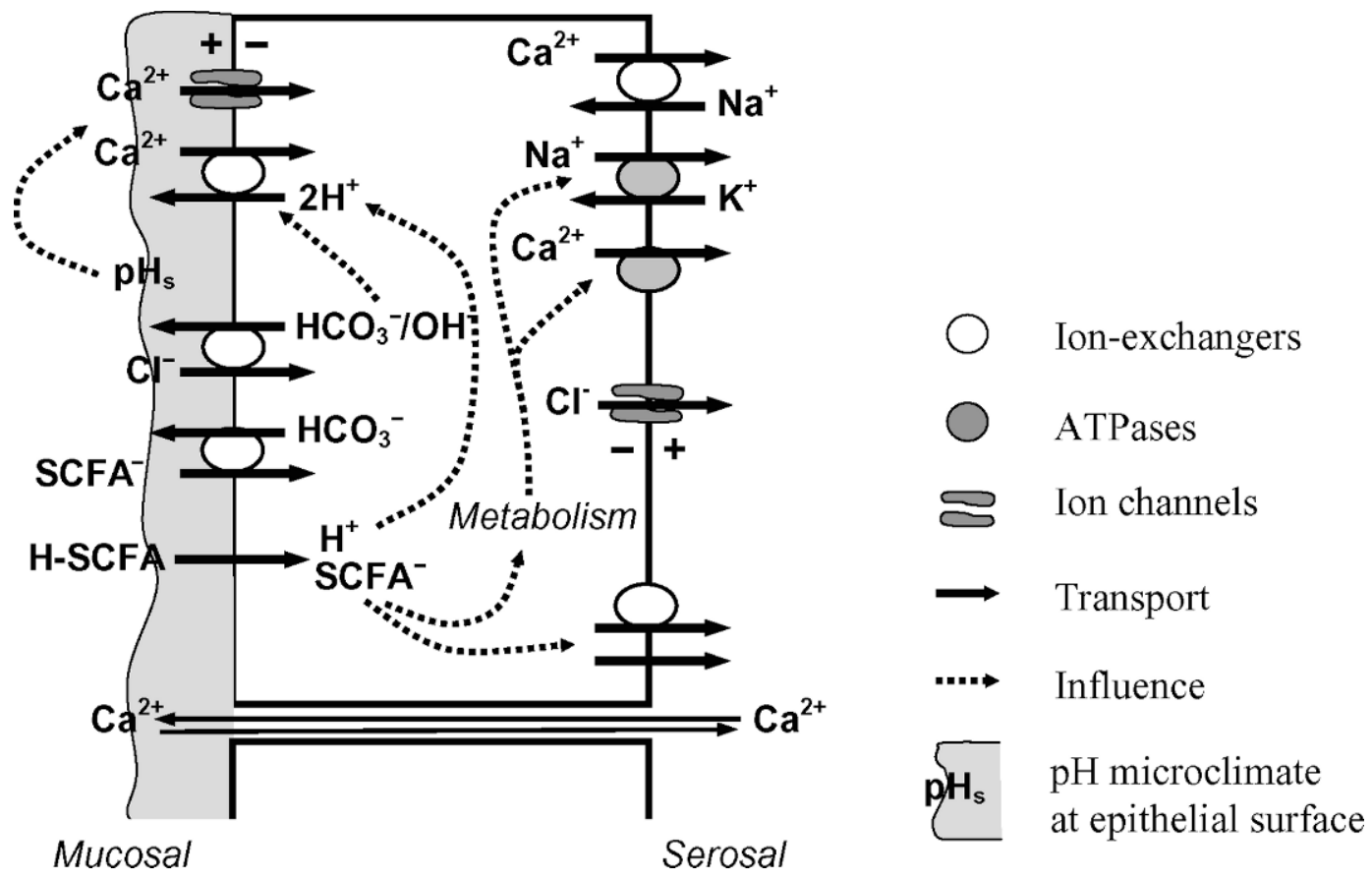

Figure 5. Schematic overview of transport processes across the rumen epithelium that could contribute to the stimulation of ruminal $\mathrm{Ca}$ absorption. $\mathrm{SCFA}^{-}=$short-chain fatty acid anion; H-SCFA = protonated short-chain fatty acid. 
channels in the distal colon of guinea pigs (ClC-2; Catalan et al., 2002). In line with the electroneutral uptake of $\mathrm{Cl}$ via luminal anion exchangers and electrogenic extrusion of $\mathrm{Cl}$ across the basolateral membrane, an acute increase in luminal $\mathrm{Cl}$ concentration depolarized the apical membrane of the rumen epithelium (Leonhard-Marek et al., 2006). Therefore, an electrogenic stimulation of $\mathrm{Ca}^{2+}$ transport via a Cl-induced alteration of electric driving forces seems rather unlikely.

Luminal $\mathrm{Cl}$ is, however, able to increase the $\mathrm{pH}$ at the epithelial surface via a stimulation of apical localized $\mathrm{Cl}^{-} / \mathrm{HCO}_{3}^{-}$or $\mathrm{Cl}^{-} / \mathrm{OH}^{-}$transporters (Figure 5; Leonhard-Marek et al., 2006). In vivo studies with the temporarily isolated rumen have shown that an increase in luminal $\mathrm{pH}$ can in turn increase ruminal $\mathrm{Ca}$ absorption (Wagner, 1998). The structures of the proteins involved in ruminal $\mathrm{Ca}$ transport are not yet known, but we have recently shown that the apical membrane of rumen epithelia from sheep and goats exhibits a nonselective cation conductance, which allows for a current of monovalent cations in the absence of divalent cations and is regulated by extracellular $\mathrm{Ca}^{2+}$ and $\mathrm{Mg}^{2+}$ as well as by intracellular $\mathrm{Mg}^{2+}$ ions (Leonhard-Marek, 2002; Leonhard-Marek et al., 2005). This phenomenon, the passage of monovalents in the absence of divalent cations, is a feature common to many $\mathrm{Ca}^{2+}$ channels (Sather and McCleskey, 2003; Hoenderop et al., 2005). In the rumen, the $\mathrm{Ca}^{2+}$ channel agonist Bay K $8644(50 \mathrm{nM})$ was able to increase $J \mathrm{Ca}_{\mathrm{ms}}$ (Wadhwa and Care, 2000), whereas verapamil, a channel blocker, decreased net Ca absorption (Schröder et al., 1997; Wadhwa and Care, 2000), which could indicate the presence of L-type $\mathrm{Ca}^{2+}$ channels in the rumen epithelium. Although many epithelia use transient receptor potential vanilloid-type $\mathrm{Ca}^{2+}$ channels for $\mathrm{Ca}$ absorption (Hoenderop et al., 2005), L-type $\mathrm{Ca}^{2+}$ channels have been suggested to contribute additionally to intestinal Ca absorption (Morgan et al., 2003). Both the epithelial transient receptor potential vanilloid-type $\mathrm{Ca}^{2+}$ channels and L-type $\mathrm{Ca}^{2+}$ channels increase their conductance with alkaline $\mathrm{pH}$ (Pietrobon et al., 1989; Vennekens et al., 2001). An increase in mucosal $\mathrm{Cl}$ concentration in the rumen could thus stimulate the electrogenic part of ruminal $\mathrm{Ca}$ absorption via an increase in surface $\mathrm{pH}$ followed by a $\mathrm{pH}$-dependent increase in luminal $\mathrm{Ca}^{2+}$ conductance (Figure 5).

For the electroneutral part of ruminal Ca absorption, a $\mathrm{Ca}^{2+} / 2 \mathrm{H}^{+}$exchange mechanisms has been suggested (Schröder et al., 1997; Wadhwa and Care, 2000). An increase in mucosal $\mathrm{Cl}$ concentration increases the activity of luminal $\mathrm{Cl}^{-} / \mathrm{HCO}_{3}{ }^{-}\left(\mathrm{OH}^{-}\right)$exchange. This has been shown by an increase in bicarbonate secretion (Gäbel et al., 1991), an increase in surface pH (Leonhard-Marek et al., 2006), and an increased recovery of isolated cells from an alkaline load in the presence of extracellular Cl (Bilk et al., 2005). Therefore, the Cldependent stimulation of electroneutral $\mathrm{Ca}$ absorption in the present study may be the consequence of an interaction between $\mathrm{Cl}^{-} / \mathrm{HCO}_{3}{ }^{-}\left(\mathrm{OH}^{-}\right)$and $\mathrm{Ca}^{2+} / 2 \mathrm{H}^{+}$exchange via intracellular $\mathrm{pH}$ or surface $\mathrm{pH}$ (Figure 5).

\section{Effects of SCFA on Ca Absorption}

A stimulatory effect of SCFA on Ca absorption across the sheep rumen epithelium has been reported by different groups (Schröder et al., 1997, 1999; Wadhwa and Care, 2000; Uppal et al., 2003) and has recently also been shown with rumen epithelia from slaughtered cattle (Ricken 2005). However, all these studies used buffer solutions in which 25 to $100 \mathrm{mM}$ SCFA were replaced by gluconate in the control solution. The current experiment demonstrated that the addition of $58 \mathrm{~m} M$ gluconate to a standard rumen buffer decreased the concentration of free $\mathrm{Ca}^{2+}$ ions from 0.8 to $0.3 \mathrm{mM}$ (Figure 3). This implies that the change from a control (gluconate) solution to an experimental (gluconate-free) solution may more than double the concentration of free $\mathrm{Ca}^{2+}$ ions. We therefore hypothesized that the stimulatory effect of SCFA might alternatively have been a blocking effect of gluconate on Ca flux rates under "control" conditions. When $J \mathrm{Ca}_{\mathrm{ms}}$ was measured in SCFA solutions without gluconate $\left(19.2 \pm 3.0 \mathrm{nmol} \mathrm{cm}^{-2} \mathrm{~h}^{-1}, \mathrm{n}=7\right.$; buffer G; SCFA in Figure 4) or with gluconate ( $13.4 \pm 0.7 \mathrm{nmol}$ $\mathrm{cm}^{-2} \mathrm{~h}^{-1}, \mathrm{n}=12$; buffer $\mathrm{B}$; low $\mathrm{Cl}$ in Figure 1), we found that gluconate could reduce $\mathrm{Ca}$ flux rates in the presence of SCFA $(P<0.05)$. In the same buffers, we also observed a huge difference in $\left[\mathrm{Ca}^{2+}\right]_{\text {ion }}$, ranging from $0.77 \pm 0.01 \mathrm{~m} M$ in the presence of SCFA alone $(\mathrm{n}=4$, buffer G) to $0.2 \pm 0.0 \mathrm{mM}$ in the presence of SCFA and gluconate $(\mathrm{n}=3$, buffer $\mathrm{B})$. However, when we exchanged mannitol for a combination of Tris-OH and SCFA without increasing the free $\mathrm{Ca}^{2+}$ concentration (Table 1), we could confirm that SCFA were indeed able to stimulate net $\mathrm{Ca}$ absorption across the rumen epithelium because of an increase in $\mathrm{JCa}_{\mathrm{ms}}$ (Figure 4). This means that the effects attributed to SCFA in the stimulation of Ca flux rates have been overestimated in previous studies, because gluconate should have decreased the control Ca flux rates in those experiments (Schröder et al., 1997, 1999; Wadhwa and Care, 2000; Uppal et al., 2003; Ricken 2005). However, the general conclusion of those studies was correct, that SCFA stimulate ruminal $\mathrm{Ca}$ absorption.

The current understanding of apical SCFA uptake in rumen epithelial cells involves the permeation of protonated SCFA, which are lipid soluble, and the uptake of SCFA ${ }^{-}$anions in exchange for $\mathrm{HCO}_{3}{ }^{-}$(Gäbel et al., 2002). A stimulation of these pathways by an in- 
crease in luminal SCFA concentration will provide protons to the cell interior and bicarbonate to the epithelial surface. This should stimulate a $\mathrm{pH}$-dependent $\mathrm{Ca}^{2+}$ conductance as well as an apical localized $\mathrm{Ca}^{2+} / 2 \mathrm{H}^{+}$ exchanger, as discussed above (Figure 5). The SCFA could thus use the same mechanisms to stimulate $\mathrm{Ca}$ absorption, as discussed above for the stimulation of $\mathrm{Ca}$ absorption by luminal $\mathrm{Cl}^{-}$ions. This conclusion is supported by a comparison of $\mathrm{JCa}_{\mathrm{ms}}$ at a high-SCFA and low-Cl luminal concentration $(19.2 \pm 3.0 \mathrm{nmol}$ $\mathrm{cm}^{-2} \mathrm{~h}^{-1}, \mathrm{n}=7$; Figure 4) with the corresponding flux rate at a high SCFA and high $\mathrm{Cl}^{-}$luminal concentration $\left(20.3 \pm 1.4 \mathrm{nmol} \mathrm{cm}^{-2} \mathrm{~h}^{-1}, \mathrm{n}=6\right.$; Figure 1). Considering these data, $\mathrm{Cl}$ seems to have no further effect on $\mathrm{Ca}$ absorption in the presence of SCFA.

Given the electrochemical gradients across the basolateral membrane (negative cell interior and low intracellular $\mathrm{Ca}^{2+}$ concentration), Ca extrusion to the blood side is an energy-dependent process. This Ca extrusion could be driven by $\mathrm{Ca}^{2+}$-ATPase (Schröder et al., 1997) or by a $\mathrm{Ca}^{2+} / \mathrm{Na}^{+}$exchange energized by the activity of the $\mathrm{Na}^{+} / \mathrm{K}^{+}$-ATPase (Höller et al., 1988; Schröder et al., 1999). Intraepithelial metabolism of SCFA, especially of $n$-butyrate, is the predominant energy source in the rumen epithelium (Baldwin and Jesse, 1992). The SCFA therefore might additionally stimulate ruminal Ca absorption by the provision of ATP. Comparison of the Ca fluxes $\left(J \mathrm{Ca}_{\mathrm{ms}}\right)$ in the presence of $\mathrm{Cl}(14.5 \pm 1.4$ $\mathrm{nmol} \mathrm{cm}{ }^{-2} \mathrm{~h}^{-1}, \mathrm{n}=8$; Figure 4) with those in the presence of Cl and SCFA (20.3 $\pm 1.4 \mathrm{nmol} \mathrm{cm}^{-2} \mathrm{~h}^{-1}, \mathrm{n}=6$; Figure 1) indicated an additional SCFA effect on $\mathrm{JCa}_{\mathrm{ms}}$ in the presence of $\mathrm{Cl}(P<0.01$ between both groups), which would agree with the hypothesized metabolic stimulation (Figure 5).

\section{Concentration of Free $\mathrm{Ca}^{2+}$ lons in Physiological Buffer Solutions}

In the freshly prepared solutions in the first experiment, $\left[\mathrm{Ca}^{2+}\right]_{\text {ion }}$ amounted to $0.75 \mathrm{~m} M$ in the high- $\mathrm{Cl}$ solution (1.2 $\mathrm{m} M$ gluconate) and to $0.22 \mathrm{~m} M$ in the low$\mathrm{Cl}$ solution (58.2 $\mathrm{mM}$ gluconate). Because the addition of gluconate reduced $\left[\mathrm{Ca}^{2+}\right]_{\text {ion }}$, whereas the addition of $\mathrm{Cl}$ had no effect (Figure 3), the values cited above can be interpreted as a reduction in $\left[\mathrm{Ca}^{2+}\right]_{\text {ion }}$ by $0.53 \mathrm{mM}$ because of the $57 \mathrm{~m} M$ gluconate.

The association of $\mathrm{Ca}^{2+}$ ions with gluconate ${ }^{-}$can be calculated as $\mathrm{K}_{\mathrm{ass}}=\left[\mathrm{Ca}\right.$-gluconate $\left.{ }^{+}\right] / \mathrm{Ca}^{2+}$ activity $\cdot$ [gluconate $\left.^{-}\right]$). For the measurements given above, $\mathrm{K}_{\mathrm{ass}}=$ 42.66 and $\log \mathrm{K}_{\mathrm{ass}}=1.63$. This value is in agreement with the $\log \mathrm{K}_{\mathrm{ass}}$ of 1.81 calculated by Christoffersen and Skibsted (1975). To estimate $\mathrm{K}_{\mathrm{ass}}$ for sulfate and SCFA, we used the $\mathrm{Ca}^{2+}$ concentrations given in Table 2 . The addition of $30 \mathrm{~m} M$ sulfate reduced $\left[\mathrm{Ca}^{2+}\right]_{\text {ion }}$ from

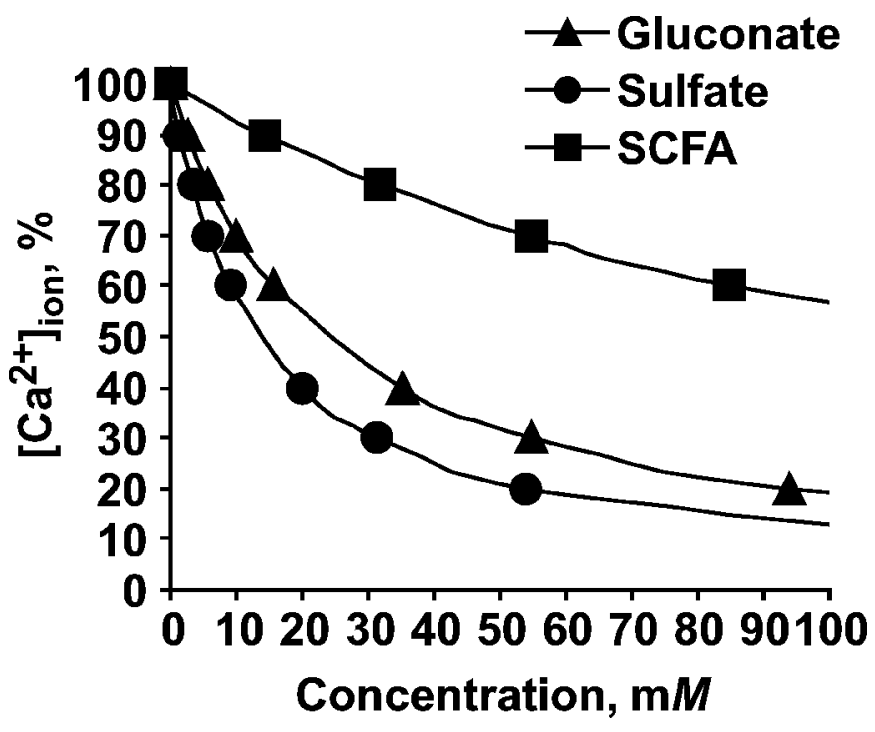

Figure 6. Proportion of free $\mathrm{Ca}^{2+}$ concentration $\left(\left[\mathrm{Ca}^{2+}\right]_{\text {ion }} \%\right)$ that can be expected in a buffer solution with substantial concentrations of gluconate, sulfate, or short-chain fatty acids (SCFA). Proportions were calculated using the equations $\mathrm{K}_{\mathrm{ass}}=\left[\mathrm{Ca}\right.$-anion $\left.{ }^{+}\right] /\left(\left[\mathrm{Ca}^{2+}\right]_{\text {ion }}\right.$ • $\left[\right.$ anion $\left.{ }^{-}\right]$) (from Christoffersen and Skibsted, 1975), and $\left[\mathrm{Ca}^{2+}\right]_{\text {ion }} \%=$ $\left[\mathrm{Ca}^{2+}\right]_{\text {ion }} \cdot 100 /\left(\left[\mathrm{Ca}^{2+}\right]_{\text {ion }}+\left[\mathrm{Ca}\right.\right.$-anion $\left.\left.{ }^{+}\right]\right)$. The $\mathrm{K}_{\text {ass }}$ used for gluconate, sulfate, and SCFA were 42.66, 71.23, and 7.40, as shown in the Discussion section.

1.11 to $0.36 \mathrm{~m} M$, resulting in a $\mathrm{K}_{\text {ass }}$ of 71.23 ; the addition of $60 \mathrm{~m} M$ SCFA reduced $\left[\mathrm{Ca}^{2+}\right]_{\text {ion }}$ from 1.11 to $0.77 \mathrm{~m} M$, resulting in a $\mathrm{K}_{\mathrm{ass}}$ of 7.4. The same equation can be used to calculate the concentration of ionized $\mathrm{Ca}^{2+}$ that can be expected in solutions with increasing concentrations of gluconate, sulfate, or SCFA (Figure 6).

These calculations show that $20 \mathrm{~m} M$ gluconate will reduce the concentration of free $\mathrm{Ca}^{2+}$ ions by nearly $50 \%$, whereas $100 \mathrm{~m} M$ gluconate will reduce $\left[\mathrm{Ca}^{2+}\right]_{\text {ion }}$ further to only $20 \%$ of the original value in the absence of gluconate. A comparable reduction to $20 \%$ of the initial $\mathrm{Ca}^{2+}$ activity was previously reported by Kenyon and Gibbons (1977), who replaced $137 \mathrm{mM} \mathrm{Cl}$ with gluconate in Tyrode's solution. A $50 \%$ reduction in $\left[\mathrm{Ca}^{2+}\right]_{\text {ion }}$ can also be expected with $15 \mathrm{~m} M$ sulfate or in the presence of about $100 \mathrm{~m} M$ SCFA (Figure 6).

These data shown in Figure 6 can be used as an estimate of $\left[\mathrm{Ca}^{2+}\right]_{\text {ion }}$ reduction in comparable solutions. However, differences in ionic composition between solutions will affect $\left[\mathrm{Ca}^{2+}\right]_{\text {ion }}$ (Günzel et al., 2005). In experiments in which $\left[\mathrm{Ca}^{2+}\right]_{\text {ion }}$ is crucial, it should be measured instead of calculated.

\section{Misestimation of Flux Rates and Possible Effects on Paracellular Permeability}

Studies of nutrient and electrolyte transport mechanisms across the forestomach or hindgut epithelia often 
use an SCFA gradient to mimic what happens in vivo. On the blood side, this amount of SCFA is frequently replaced by gluconate in the respective solutions, because gluconate gradients are considered to have only negligible effects on transport rates. However, in light of the reduced free $\mathrm{Ca}^{2+}$ concentration in a gluconate buffer, as shown above, such a strategy would lead to a misestimation of flux rates from the serosal to the mucosal side, if the flux rate is at all dependent on the available concentration of free $\mathrm{Ca}^{2+}$ ions. For Ca flux rates, this dependence is a direct one.

When the experiments in the present study were compared, there was a significant difference in $\mathrm{JCa}_{\mathrm{sm}}$ between the 2 control conditions (gluconate and mannitol), which was correlated with a difference in free $\mathrm{Ca}^{2+}$ ions. All epithelia bathed in a gluconate solution $\left(\left[\mathrm{Ca}^{2+}\right]_{\text {ion }}=0.31 \mathrm{mM}\right)$ on the serosal side showed a mean $J \mathrm{Ca}_{\mathrm{sm}}$ of $2.75 \pm 0.31 \mathrm{nmol} \mathrm{cm}{ }^{-2} \mathrm{~h}^{-1}(\mathrm{n}=18)$, whereas epithelia bathed in the mannitol control solution $\left(\left[\mathrm{Ca}^{2+}\right]_{\text {ion }}=1.11 \mathrm{mM}\right)$ showed a higher $J \mathrm{Ca}_{\mathrm{sm}}$ of $5.40 \pm$ $0.42 \mathrm{nmol} \mathrm{cm} \mathrm{cm}^{-2} \mathrm{~h}^{-1}(\mathrm{n}=20, P<0.001$ vs. gluconate solution). This higher transport rate was not due to a higher transepithelial conductance in the second group of tissues. Tissues bathed in the mannitol solution even showed a lower $G_{t}\left(1.13 \pm 0.05 \mathrm{mS} \mathrm{cm}^{-2}\right)$ than those bathed in the gluconate solution $\left(\mathrm{G}_{\mathrm{t}}=2.21 \pm 0.13 \mathrm{mS}\right.$ $\mathrm{cm}^{-2}, P<0.001$ ), which might point to a higher paracellular permeability in a gluconate solution because of the reduction in $\left[\mathrm{Ca}^{2+}\right]_{\text {ion }}$.

Besides the increased $\left[\mathrm{Ca}^{2+}\right]_{\text {ion }}$, an additional explanation for the higher $\mathrm{JCa}_{\mathrm{sm}}$ in the mannitol control solution might be the lower Na concentration in these solutions. (To study the isolated effect of anion addition and end up with the same anion concentrations as in the first experimental series, we had accepted a difference in $\mathrm{Na}$ concentration between the 2 series as the smaller deviation.) Up to now, no structural or functional studies have been conducted on the mechanisms mediating basolateral Ca efflux from the rumen epithelium, but the observation that ouabain, a blocker of $\mathrm{Na}^{+} / \mathrm{K}^{+}$-ATPase, reduced $J \mathrm{Ca}_{\mathrm{ms}}$ and increased $\mathrm{JCa}_{\mathrm{sm}}$ (Höller et al., 1988) would support the involvement of $\mathrm{Na}^{+} / \mathrm{Ca}^{2+}$-exchangers at the basolateral membrane. The existence of a significant electroneutral component of $J \mathrm{Ja}_{\mathrm{sm}}$ (Höller et al., 1988; present study) could further point to a transcellular Ca secretion via Ca exchangers operating in reverse mode. Thus, a reduction in serosal Na concentration together with the increase in $\left[\mathrm{Ca}^{2+}\right]_{\text {ion }}$ might entail basolateral $\mathrm{Ca}$ uptake and an increase in $J C a_{\mathrm{sm}}$. However, we did not observe a decrease in $J \mathrm{Ca}_{\mathrm{ms}}$ under the conditions of a reduced $\mathrm{Na}$ concentration (cf. SCFA in Figure 4 vs. high $\mathrm{Cl}$ and SCFA in Figure 2), which argues against a major contribution of $\mathrm{Na}^{+} / \mathrm{Ca}^{2+}-$ exchange for transcellular $\mathrm{Ca}$ absorption or against its operation in reverse mode despite the reduced $\mathrm{Na}$ concentration.

Although we did not find differences between $J \mathrm{Ca}_{\mathrm{sm}}$ measured with different solutions on the mucosal side, an altered $\left[\mathrm{Ca}^{2+}\right]_{\text {ion }}$ on the mucosal side might likewise alter the chemical gradient and thereby have an effect on $\mathrm{JCa}_{\mathrm{sm}}$, if the contribution of other variances is small. This might be one cause for the decreased electroneutral component of $J \mathrm{Ca}_{\mathrm{sm}}$ measured in a high-Cl buffer mucosal $\left(\left[\mathrm{Ca}^{2+}\right]_{\text {ion, mucosal }}=0.8 \mathrm{mM}\right)$ compared with the value measured in a low-Cl (high-gluconate) solution on the mucosal side $\left(\left[\mathrm{Ca}^{2+}\right]_{\text {ion, mucosal }}=0.2 \mathrm{mM}\right)$. The possible misestimation of $J_{\mathrm{sm}}$ flux rates attributable to gluconate solutions discussed here will, as a consequence, lead to a misestimation of net absorption rates, because $J_{\mathrm{net}}=J_{\mathrm{ms}}-J_{\mathrm{sm}}$.

\section{CONCLUSIONS}

Chloride and SCFA stimulate active $\mathrm{Ca}$ absorption across the rumen epithelium. The available data suggest that this stimulation is due to $\mathrm{pH}$ effects on $\mathrm{Ca}^{2+}$ channels and on a putative $\mathrm{Ca}^{2+} / 2 \mathrm{H}^{+}$exchange, with additional metabolic effects of SCFA. Sulfate had no effect on Ca absorption, whereas gluconate decreased Ca flux rates. The effect of gluconate could be correlated to a reduction in the concentration of free $\mathrm{Ca}^{2+}$ ions, which were also reduced by sulfate and SCFA anions. These data mean that ion-exchange experiments must be evaluated very carefully, because changes in $\left[\mathrm{Ca}^{2+}\right]_{\text {ion }}$ in the presence of gluconate, sulfate, or SCFA might not only entail an underestimation of Ca flux rates, but might also have effects on other $\mathrm{Ca}^{2+}$-dependent pathways.

Based on the effects of $\mathrm{Cl}$ and SCFA on ovine ruminal Ca absorption in the present study, and the effects of SCFA on bovine ruminal Ca absorption (Ricken, 2005), Ca salts included in the diets of dairy cows postpartum should be supplied as chlorides (in concentrations or formulations that are not caustic) or as salts of SCFA, preferably as propionate because of its additional glucogenic and energetic benefits.

\section{ACKNOWLEDGMENTS}

The technical assistance of M. Burmester and U. Dringenberg is greatly appreciated.

\section{REFERENCES}

Baldwin, R. L., 6th, and B. W. Jesse. 1992. Developmental changes in glucose and butyrate metabolism by isolated sheep ruminal cells. J. Nutr. 122:1149-1153.

Bilk, S., K. Huhn, K. U. Honscha, H. Pfannkuche, and G. Gäbel. 2005. Bicarbonate exporting transporters in the ovine ruminal epithelium. J. Comp. Physiol. B 175:365-374. 
Catalan, M., I. Cornejo, C. D. Figueroa, M. I. Niemeyer, F. V. Sepulveda, and L. P. Cid. 2002. ClC-2 in guinea pig colon: mRNA, immunolabeling, and functional evidence for surface epithelium localization. Am. J. Physiol. Gastrointest. Liver Physiol. 283:G1004-G1013.

Chien, W.-J., and C. E. Stevens. 1972. Coupled active transport of $\mathrm{Na}$ and $\mathrm{Cl}$ across forestomach epithelium. Am. J. Physiol. 223:997-1003.

Christoffersen, C. R., and L. H. Skibsted. 1975. Calcium ion activity in physiological salt solutions: Influence of anions substituted for chloride. Comp. Biochem. Physiol. A 52:317-322.

Frizzell, R. A., and S. G. Schultz. 1972. Ionic conductances of extracellular shunt pathway in rabbit ileum. Influence of shunt on transmural sodium transport and electrical potential differences. J. Gen. Physiol. 59:318-346.

Gäbel, G., J. R. Aschenbach, and F. Müller. 2002. Transfer of energy substrates across the ruminal epithelium: Implications and limitations. Anim. Health Res. Rev. 3:15-30.

Gäbel, G., M. Bestmann, and H. Martens. 1991. Influences of diet, short-chain fatty acids, lactate and chloride on bicarbonate movement across the reticulo-rumen wall of sheep. J. Vet. Med. A 38:523-529.

Grace, N. D., M. J. Ulyatt, and J. C. MacRae. 1974. Quantitative digestion of fresh herbage by sheep. III. The movement of $\mathrm{Mg}$, $\mathrm{Ca}, \mathrm{P}, \mathrm{K}$ and $\mathrm{Na}$ in the digestive tract. J. Agric. Sci. 82:321-330.

Günzel, D., J. A. S. McGuigan, and W. R. Schlue. 2005. Use of $\mathrm{Mg}^{2+}$ and $\mathrm{Ca}^{2+}$ macroelectrodes to measure binding in extracellularlike physiological solutions. Front. Biosci. 10:905-918.

Hoenderop, J. G., B. Nilius, and R. J. Bindels. 2005. Calcium absorption across epithelia. Physiol. Rev. 85:373-422.

Höller, H., G. Breves, M. Kocabatmaz, and H. Gerdes. 1988. Flux of calcium across the sheep rumen wall in vivo and in vitro. Q. J. Exp. Physiol. 73:609-618.

Kenyon, J. L., and W. R. Gibbons. 1977. Effects of low-chloride solutions on action potentials of sheep cardiac Purkinje fibers. J. Gen. Physiol. 70:635-660.

Khorasani, G. R., R. A. Janzen, W. B. McGill, and J. J. Kennelly. 1997. Site and extent of mineral absorption in lactating cows fed whole-crop cereal grain silage or alfalfa silage. J. Anim. Sci. 75:239-248.

Leonhard-Marek, S. 2002. Divalent cations reduce the electrogenic transport of monovalent cations across rumen epithelium. J. Comp. Physiol. B 172:635-641.

Leonhard-Marek, S., G. Breves, and R. Busche. 2006. Effect of chloride on $\mathrm{pH}$ microclimate and electrogenic $\mathrm{Na}^{+}$absorption across the rumen epithelium of goat and sheep. Am. J. Physiol. Gastrointest. Liver Physiol. 291:G246-G252.

Leonhard-Marek, S., G. Gäbel, and H. Martens. 1998. Effects of short chain fatty acids and carbon dioxide on magnesium transport across sheep rumen epithelium. Exp. Physiol. 83:155-164.

Leonhard-Marek, S., B. Schröder, and G. Breves. 2000. Einfluss der Cl-Konzentration auf den ruminalen Ca-Transport bei Schafen (Influence of $\mathrm{Cl}$ concentration on Ca transport across sheep rumen epithelium). Proc. Soc. Nutr. Physiol. 9:126. (Abstr.)

Leonhard-Marek, S., F. Stumpff, I. Brinkmann, G. Breves, and H. Martens. 2005. Basolateral $\mathrm{Mg}^{2+} / \mathrm{Na}^{+}$exchange regulates apical non-selective cation channel in sheep rumen epithelium via cytosolic $\mathrm{Mg}^{2+}$. Am. J. Physiol. Gastrointest. Liver Physiol. 288:G630-G645.

Martens, H., G. Gäbel, and B. Strozyk. 1991. Mechanism of electrically silent $\mathrm{Na}$ and $\mathrm{Cl}$ transport across the rumen epithelium of sheep. Exp. Physiol. 76:103-114.
Morgan, E. L., O. J. Mace, P. A. Helliwell, J. Affleck, and G. L. Kellett. 2003. A role for $\mathrm{Ca}(\mathrm{v}) 1.3$ in rat intestinal calcium absorption. Biochem. Biophys. Res. Commun. 312:487-493.

Pietrobon, D., B. Prod'hom, and P. Hess. 1989. Interactions of protons with single open L-type calcium channels. $\mathrm{pH}$ dependence of proton-induced current fluctuations with $\mathrm{Cs}^{+}, \mathrm{K}^{+}$, and $\mathrm{Na}^{+}$as permeant ions. J. Gen. Physiol. 94:1-21.

Rayssiguier, Y., and C. Poncet. 1980. Effect of lactose supplement on digestion of lucerne hay by sheep. II. Absorption of magnesium and calcium in the stomach. J. Anim. Sci. 51:186-192.

Ricken, G. E. 2005. Transport von Calcium über das isolierte Pansenepithel des Rindes. (Calcium transport across isolated bovine rumen epithelium). Diss. Tierärztliche Hochschule, Hannover, Germany.

Sather, W. A., and E. W. McCleskey. 2003. Permeation and selectivity in calcium channels. Annu. Rev. Physiol. 65:133-159.

Schröder, B. 1996. Vergleichende Physiologie der gastrointestinalen Calcium- und Phosphatresorption bei Schweinen und kleinen Wiederkäuern (Comparative physiology of gastrointestinal calcium and phosphate absorption in pigs and small ruminants). Habilschrift, Justus Liebig Univ., Gießen, Germany.

Schröder, B., I. Rittmann, E. Pfeffer, and G. Breves. 1997. In vitro studies on calcium absorption from the gastrointestinal tract in small ruminants. J. Comp. Physiol. B 167:43-51.

Schröder, B., S. Vössing, and G. Breves. 1999. In vitro studies on active calcium absorption from ovine rumen. J. Comp. Physiol. [B] 169:487-494.

Schweigel, M., M. Freyer, S. Leclercq, B. Etschmann, U. Lodemann, A. Böttcher, and H. Martens. 2005. Luminal hyperosmolarity decreases $\mathrm{Na}$ transport and impairs barrier function of sheep rumen epithelium. J. Comp. Physiol. B 175:575-591.

Skibsted, L. H., and G. Kilde. 1972. Dissociation constant of calcium gluconate. Calculations from hydrogen ion and calcium ion activities. Dansk Tidsskr. Farm. 46:41-46.

Uppal, S. K., K. Wolf, and H. Martens. 2003. The effect of short chain fatty acids on calcium flux rates across isolated rumen epithelium of hay-fed and concentrate-fed sheep. J. Anim. Physiol. Anim. Nutr. (Berl.) 87:12-20.

Vennekens, R., J. Prenen, J. G. J. Hoenderop, R. J. M. Bindels, G. Droogmans, and B. Nilius. 2001. Modulation of the epithelial $\mathrm{Ca}^{2+}$ channel ECaC by extracellular pH. Pflügers Arch., Eur. J. Physiol. 442:237-242.

von Engelhardt, W. 1969. Der osmotische Druck im Panseninhalt. (The osmotic pressure in rumen contents). Zbl. Vet. Med. A 16:665-690.

Wadhwa, D. R., and A. D. Care. 2000. The absorption of calcium ions from the ovine reticulo-rumen. J. Comp. Physiol. [B] 170:581-588.

Wagner, C. 1998. In vivo Untersuchungen zum Einfluß kurzkettiger Fettsäuren und des $\mathrm{pH}$-Wertes auf die Bewegungen von Calcium, Magnesium, Kalium und Phosphat durch die Wand des Retikulorumens von Schafen mit unterschiedlicher Calcium-Versorgung. (In vivo investigations to characterize the influence of short chain fatty acids and $\mathrm{pH}$ value on the movement of $\mathrm{Ca}, \mathrm{Mg}, \mathrm{K}$ and $\mathrm{P}_{\mathrm{i}}$ across the reticulo-rumen wall of sheep kept on different dietary Ca supply.) Diss. Univ. Leipzig, Leipzig, Germany.

Warner, A. C., and B. D. Stacy. 1965. Solutes in the rumen of the sheep. Q. J. Exp. Physiol. 50:169-184.

Wylie, M. J., J. P. Fontenot, and L. W. Greene. 1985. Absorption of magnesium and other macrominerals in sheep infused with potassium in different parts of the digestive tract. J. Anim. Sci. 61:1219-1229. 